\title{
Reflection of cross-cultural conflicts in perception of the Yakut literary works by the foreign students
}

\author{
Gavril Starostin', Natalya Archakhova ${ }^{1, *}$, Maria Daineko², and Maya Slobodchikova ${ }^{2}$ \\ ${ }^{1}$ M.K.Ammosov North-Eastern Federal University, 58 Belinskogo Str., Yakutsk 677000, Russian Federation \\ ${ }^{2}$ St. Petersburg State Pediatric Medical University, 2 Litovskaya Str, Saint Petersburg 194100, Russian Federation
}

\begin{abstract}
The article focuses on the perception of Yakut literary texts by students - representatives of different nations and countries. The authors have chosen three classical works of famous Yakut writers as subjects of the research - V.S. Yakovlev-Dalan "Glukhoi Viluy / Tulaaiakh ogho" ("The Remote Viluy River"), a drama of A.I. Sofronov-Alampa «Taptal» («Любовь»)"Love” and a story of N.G. Zolotarev (Nikolay Yakutskiy) «Kemusteekh yuryuie» («Золотой ручей») ”Golden Stream”. It is stated that acquaintance with other cultures through literary works can be one of the most effective ways of intercultural communication as it helps better understanding of cultural diversities. Such cultural conflicts as murder (killing a kin), women's rights and the loss of historical lands of the local people with the coming of the representatives of other cultures are described and analyzed. The research predictably revealed the differences in the perception of the respondents as their answers have been discussable and variable, especially among the representatives of the eastern and the western worlds though their attitude in common are the same for all human beings. Those concepts which were culturally arguable provoked serious thought process. As a result of the research it can be stated that cross-cultural conflicts can have not only a destructive function but also a constructive one as well.
\end{abstract}

\section{Introduction}

E. Hall and J. Trager developed the term "intercultural communication" in 1954, so since 1960s this idea has become the objective of many investigations. Most of them were devoted to historical aspects, and the main issue is that the culture is reflected in language. Nowadays intercultural communication is still a dynamically developed subject, because an effective intercultural communication is becoming more and more necessary. Therefore, Russian science deals with intercultural communication through the teaching of foreign languages. Most Russian scientists believe that methods of teaching a foreign language have tight connection with trends of understanding another culture, mentality, and way of life situation perception.

Recently scientists have observed proneness to conflict increase practically in any area of human life activity. Quite often these misunderstandings are not connected with the level of language knowledge but with the absence or quite low level of the knowledge of another culture. There is no doubt that the language knowledge correlates with the proper understanding of people of different cultures. Usually the ignorance of another culture becomes the main reason of the cultural conflict. It is still a great problem to train an international person who is able to communicate understanding every doubtful intercultural moment.
However, along with this there can be observed the wish to arrange a productive dialogue in the sphere of intercultural communication, the primary objective of which is proneness to conflict decrease in the process of intercultural and interpersonal communication. "Cultural space of our society includes variety of subsystems, the most significant of them are the following. 1) The territory cultural space is a system of values, traditions, norms of behaviour and etiquette, mentality that distinguishes the members of one territory from the others. 2) The cultural space of community is a system of values, traditions, norms of behaviour and etiquette, mentality that distinguishes members of one community from the others. 3) The cultural space of social organizations is a system of values, traditions, norms of behaviour and etiquette, mentality that distinguishes members of one organization from the others" [1].

All humans are much more similar than different, so, we might think that such notions as love, family, friendship, health or death are perceived equally worldwide. But, according to some investigations, people from different countries and of different nations give these values not the same places concerning their importance. So, for example, Chinese respect older generations more compared with Americans, Koreans consider love and friendship less important for proper life than Americans do. Some nations think that speaking loudly is a sign of fight, but some suppose it is an emotionally pronounced statement. Thus, the problem of

\footnotetext{
Corresponding author: archakhova@mail.ru
} 
intercultural communication is deeper, because we should take into account the issues that characterize another culture - politics, religion, and economy. People understand the differences in these differently; their attitudes towards the cultural diversities are sometimes confronted. Unfamiliar pattern of behavior can become a puzzle for a person brought up with other cultural views. Proper understanding and acceptance can occur only if a person is involved in some social activity connected with another culture. Through real-life stories you will be able to see the way people of another culture behave, understand, and perceive different aspects of life situations. Education in this sphere can be achieved by such activities as personal or community interactions, travelling, learning the meaning of folktales and proverbs, watching movies, and reading books created by representatives of another culture. Due to this, one will be able to understand cultural orientations, to identify cultural similarities, to assess intercultural conflicts, and to develop an appropriate way to perceive the intercultural conflict situation and to build crosscultural relationships in the most fruitful manner.

The novelty is defined by the material of the research work when the Yakut literary works become the points for reflection of cross-cultural conflicts perceived by the foreign readers.

\section{Materials and Methods}

The texts were chosen according to the following criteria:

- the texts should be literary works where all the sides of the populations are described;

- the texts should reflect the fragments of the historical realia for the described period;

- the texts should be rich in cultural components like descriptions of the traditions, mode of everyday life, routine behaviour of the protagonists, and represent the world views of the Sakha, the Evenks and the kin of the Tong Biis;

- the texts should be short and provide enjoyment to the readers so that to obtain more informative and effective results.

The following methods were used: the analysis of revealing reflections of cross-cultural conflicts in the Yakut literary works was performed including contentbased critical analysis of the text, structural approach, historicism and typologically systemic methods. The data were collected by means of a sample survey and comparative analysis.

Hypothesis: We suppose that the national worldviews of the Yakuts, the Evenks and the ancient kin of the Tong-Biis are reflected in the Yakut literary works. They reflect national and cultural peculiarity of each linguo-cultural aspect of the community. Revealing peculiarities is possible only from the point of view of the respondents' cultural background; their point of view is practically significant to comparative analysis.

The research work is practically and theoretically significant because the obtained data promote the idea of perception of the foreign literature, thus the results can become a background to develop the methods of literary work analysis in the process of teaching at higher educational institutions.

We have prepared the retelling of the plot of the original texts, where we included the moments that could be hardly understood by the foreign representatives with the other cultural background. We introduced the texts.

We asked to note the parts / situations of the texts which they find difficult to understand; these parts or situations which were unfamiliar to their culture; and answer several questions. Here they represented their own attitude towards the causes which they find important (the respondents introduced their answers in a written form).

\section{Results}

As a result of the analysis we explained and interpreted the cases which the respondents found odd and uncommon. The method of a sample survey revealed the attitudes of the foreign respondents to such common human concepts like death $v s$. murder, unequal marriage and love to the homeland through the prism of the Yakut literary works perception.

\section{Discussion}

The conflict of cultures became one of the most important problems of humanity from the time of globalization. Cultural conflict is a form of unacceptability or dislike of political views, struggle between two or more opposite ideologies, world outlooks, cultural values or mentalities. Sociologists point out that such conflicts are very difficult to solve because of differences in religions, moral cultures of nationalities, ethnicities or nations. T.B. Frik writes in her scientific article that the problem of conflict of cultures involves all types of human life and activity during any contacts with other cultures, including "single-sided" ones: in case of foreign literature reading, introduction to foreign art [2].

Literary works play an important role in the process of intercultural communication as they are directly connected with culture and contain the information about the history of national psychology and behavior which are the parts of culture [3].

The aim of this study was to make the analysis of reflection of cultural conflicts during the perception of the Yakut literary works by the foreign students. We considered three classical works of the Yakut literature: a historical novel of the Yakut literature written by V.S. Yakovlev-Dalan "Glukhoi Viluy / Tulaaiakh ogho" ('The Remote Viluy River"), a drama of A.I. SofronovAlampa «Taptal» («Любовь»)"Love" and a story of N.G. Zolotarev (Nikolay Yakutskiy) «Kemusteekh yuryuie » («Золотой ручей»)" Golden Stream” as a part of conflict and, as a consequence, reflection of cultural conflicts during the perception of the Yakut literary 
works by foreign students. The object of our study is the conflict as a socially significant phenomenon involving many factors of human life activity (within their national culture), and the subject of our study is the cultural conflict in perception of the texts of the Yakut writers.

In culturological space, to be more exact in a scientific sphere of cultural anthropology, the concept of the conflict of cultures is very urgent nowadays. Those scientists who work in this area, arrange scientific conferences and round table discussions, universities have such disciplines as "intercultural / cross-cultural communication", "area studies", "the studied language world" and others. The analysis of cultural globalization brings up a loaded question about forms and types of conflicts. For example, the scientists identify some forms of cultural conflicts: "Between various ethnic groups and their cultures...; religious groups, representatives of different religions or trends in some religions...; generations, members of different subcultures..." [4]. Thus, S.G. Ter-Minasova and T.B. Frik identify two forms of the conflict in their works, "occurrence of the direct conflict of cultures is possible. It is possible to define contacts and conflicts with foreign culture (books, films, language, etc.) as indirect, mediated" [5]. We will adhere to the last idea statement in this research work.

As it has been mentioned above, we considered three literary works different in typology of literary genres: a story, a novel and a drama. Foreign representatives having academic training in Mid Sweden University were interviewed by the method of selective questioning. $70 \%$ of them are citizens of France, Sweden, Belgium, Moldova, Germany, Spain, Thailand, and 30\% are the students from national republics of the Russian Federation: the Republics of Tyva, Altai and Bashkortostan. The respondents were offered to get to know the content of the literary works taken for this study by any convenient method: by paper book (in a full variant or in a summary), by audio-version, by watching a film («The Remote Viluy River») or a theatre performance («Taptal» (Love). According to the results of the analysis, questioning and extensive interview the reflection of cultural conflicts in perception of the Yakut literary works by foreign students was identified.

1. A novel "Glukhoi Viluy / Tulaaiakh ogho" ('The Remote Viluy River") recalls genetic memory of the nation, which described history of the kins (agha uuha) represented by the Tumats, Tong Biis, Djirikinei, Chaabiigir, Maiaat, Khoro and others including Uraanghai Sakha. The events of the novel took place in the XVI century - before Yakutia became a part of Russia when Sakha people suffered from civil rivalry. The base of the novel is founded on folktales and legends of the Sakha people. "The Remote Viluy River" chronotope, a coordinated time and space representation in the structure of the text, is the novel written by V.S. Yakovlev - Dalan, it describes the breaking period in the history of the nation formation 'kyrgys kem'. Thus, the author describes how a grandson Daghancha had to kill his grandfather Bakamdy before leaving for tong biis meeting, tong biis was a generic clan, while Daghancha together with Bakamdy belonged to other kins of the Tumats. The situation described by Dalan here shows the way of life the different clans had. The respondents of the research work showed their attitudes to the issue through the prism of their own culture. $100 \%$ showed negative attitude to the concepts of killing and beating, no matter, who the victim is a kin or any member of the society. For example, one of the female respondents from France answered: "This is where the issue is complicated in France: killing someone, even a family member who has expressed a wish to die, is forbidden and considered a crime. In my opinion, it is not up to another person to kill someone who wants to die". A student from Thailand says, "I would not kill the grandfather if I were him. From the perspective of Thais, killing people is karma, suicide is also karma. People should die at the proper time naturally". (Here and forth we bring the quotes of the brightest responds, the quotes are represented in the appendix below.) Thus, the respondents hold the same view that they will not outrage and kill their family member being guided by their own principles for the sake of profit. It seems that this is one of the signs of globalization, when the developed nations become more tolerant and human. However it can be associated with the respondents' personal backgrounds, almost all the respondents are from the democratic and liberal countries besides the one from Thailand, a country with a constitutional monarchy. As for the respondents from the Russian Federation, they are included into the group of the foreign respondents as being the representatives of the other culture.

The concept of killing a kin is a taboo concept for all the human beings. Dalan here arouses such conflict to show the historical context of that time when the oldest of the kin chooses to be killed by his closest relative rather than by the enemy who would probably invade his territory. The respondents perceived the main idea of killing without being introduced to the whole context that is why the idea is blamed. On a whole killing is perceived as a criminal attitude from the modern viewpoint of today's life with democratic and liberal background.

2. A classic of the Yakut literature A.I. Sofronov Alampa in his drama "Lyubov / Taptal" ("Love") represented thorny issues of that time, which dealt with society and life arrangements. Here an issue of the social position of the Yakut woman in feudal and patriarchal society is discussed. At the end of the XX, women had no rights. The woman lost her health due to difficult life conditions, permanent lack of livelihood and work beyond her strength. There was a high mortality rate of the newborns, when only one or two could survive out of the ten newborns. The woman was financially and morally dependent on her husband and his parents. Moreover, the woman had no legal rights. Alampa's play describes a female protagonist Ketiriis, an orphan girl who was left alone and was married a rich man by her relatives without asking her. She was unhappy and got into a tragic conflict with her life. Her uncle (an older brother of her father) married her with an old and cruel man who bit her and raped till death at the final of the play. The respondents bit the situation, 100\% condemned the unfair social system and supported Ketiriis, who was a victim of the social environment. 
However it should be noted that the respondents from the Turkic speaking republics got the main idea and conflict of the play, other $70 \%$ of the respondents strongly objected such attitude in their countries. They say, "I would let her marry her beloved man. I don't think this exists here in Sweden but some cultures still find its way here so if it's happening here. I don't think it's something that would be talked about", "I condemn this situation, since everyone can choose when and with whom to marry. There is no such ritual in my country, I think it's disgusting to sell people" and "This situation, in my opinion, is disgusting, conservative and sexist. It violates and infringes upon a woman's freedom to marry a man she loves. In France, the Declaration of the Rights of Man and of the Citizen as well as the law and the motto "Liberty, Equality and Fraternity" show that each person is free to make his own choices in life. Also, marriage before the age of majority is forbidden in France as well as forced marriages. According to article 16 (2) of the Universal Declaration of Human Rights, forced marriage is an infringement of fundamental human rights, including freedom and physical integrity. Everyone has the right to choose his or her spouse".

The respondents showed unanimous opinion blaming unequal and obedient behaviour of the protagonist.

3. Nikolay Yakutskiy was the first to write about the discoverers and gold miners. A story "Zolotoy ruchey" ("Golden Stream") depicts the period from the 90-s of the XIX to 1927. The author describes the history of discovering the gold fields and mining in the Ulakhan region. The main idea of the story is addressed to Uybaancha, a young hunter, who is asked not to tell about gold fields along the river Uchur, he was told by an old and experienced Evenk hunter Sedjuk. Sedjuk banned to tell about gold which they discovered on the territory of their reindeer-breeding fields. Sedjuk says that "gold is not the Evenks' wealth", meaning that the other people will come to mine gold, they will develop industry and the reindeer-breeding fields will be lost as well as the routine life for the local inhabitants. He says:" There will be no hunting, no deer and no nation". A Russian proverb tells that there is no nation without culture. Gold-mining is commonly associated with wealth, treasure and a way to wealthy life. As for the main protagonist of the story gold mining can result in a cause-and-effect relation between assimilation and a loss of identity for the Evenks. The Evenks will lose their lands because there will develop gold-mining industry when many people arrive from different places to banish the native citizens from their home lands. The main issue was revealed only by one of the respondents, who was from the Republic of Tyva. Thus we can see that the historical background and national world-view of the Yakuts and the Tyvans are somewhat close.

Thus, it would be remarkable to note the words of prominent Russian academician D.S. Likhachev. He mentioned that each word, meaning and concept are wider and richer in each person whose cultural background is richer and wider, the less is the cultural background of the person the poorer the language he knows the narrower the "concept sphere" he obtains [6]. Here we can see how discussable and variable the answers of the respondents were. They showed their attitude towards different concepts that are common for all human beings on the one hand, and culturally arguable from the other. In some cases, we can see variability of answers of the Western opinion as opposed to the Eastern one that is reflected in the concept of attitude to the death and an attempt to preserve lands and tradition. All the respondents, notably female ones, undisputedly disagreed with the idea of getting married without agreement from the bride, rude attitude towards the women, lack of equal rights.

\section{Conclusion}

We should note that reading foreign literature is inevitably accompanied with introduction of alien culture and its conflict. Reading literary works of foreign writers namely the comparison of cultures reveals the depth of problems of intercultural communication. The main reason of misunderstanding is not different languages as texts can be translated. The main reason is different national consciousnesses. The perception of the images of other cultures occurs either through the attempt to find similarities (equivalents) in the readers' culture or through finding differences. The personality of the reader is of great importance too as it influences the perception of the work. Personal characteristics, age, life experience affects the understanding of a storyline and a whole narrative. But the peculiarities of reader's perception and interpretation of events in a literary work are defined not only his personal characteristics but also by the peculiarities of his/her national culture.

So, reading is not only perception but also a communication process. And mechanic transferring of the stereotypes of one culture to another provokes communicative malfunctioning and makes it more difficult to understand the main message of the literary work properly. Thus, background knowledge is a necessary component part of holistic views of texts.

We should not also ignore the fact that vertical context plays an important role in perception of literary works as well. So it can be stated that literary works of foreign writers are effective means of understanding not only different cultures but also historical events and national psychology.

Thus, we should note that in such field of communication, intercultural conflict has not only unclear destructive function but also diagnostic and constructive ones. First of all, its diagnostic function consists of recognition of immediate causes of behavior in conflict situation, choosing characteristic strategies and styles of the communicative interactions, thus, possibly resulting in stabilization of interpersonal relations in the society and becoming an effective means of intercultural communication. The constructive function of the conflict promotes development of interrelation and understanding, thus preventing stagnation and enhancing cognitive role. In terms of this research work, it can practically check and correct the 
views of the respondents, thus resulting in both formation of the resource and development of effective communicative competence. The process of the conflict can improve understanding of own culture, own worldview, own approach to life and attitude to people more profoundly. Such correlation ensures objectivity of the obtained results.

\section{References}

1. T. M. Balandina Vest. Sarat. Gos. Soc. Econ. Univ. 1 (40), 170 (2012)

2. T. B. Frik Fundamentals of Theory of CrossCultural Communication 83 (2013)

3. T.A. Bobkova Vest. Bashk.Univ. 14 (2), 471 (2009)

4. N. M. Bogoliubova. Cross-Cultural Communication Part I, 89 (2018)

5. S. G. Ter-Minasova Language and CrossCultural Communicaton 84 (2000)

6. D. S. Likhachev Rus Lit: Fr Theory of Lit to Str. 152 (1997) 